\title{
MICROBIAL BIOMASS AND ENZYMATIC ACTIVITIES IN SANDY SOIL CULTIVATED WITH LETTUCE INOCULATED WITH PLANT GROWTH PROMOTERS $^{1}$
}

\author{
MARCELE DE CÁSSIA HENRIQUES DOS SANTOS MORAES ${ }^{2}$, ERIKA VALENTE DE MEDEIROS ${ }^{2}$, DAYANE \\ DA SILVA DE ANDRADE ${ }^{2}$, LEANDRO DIAS DE LIMA ${ }^{2}$, IVONALDO CARLOS DA SILVA SANTOS ${ }^{2}$, ARGEMIRO \\ PEREIRA MARTINS FILHO ${ }^{3}$
}

\begin{abstract}
Plant growth promoter microorganisms have been studied as important tools for increasing crop production. Lettuce is the most consumed hardwood crop in the world. Numerous microorganisms are capable of acting in a beneficial way in the growth of this culture. The objective of the present study was to evaluate the efficacy of Trichoderma and Pseudomonas on the microbial biomass, enzymatic activities in sandy soil and lettuce production. The experimental design was completely randomized with ten replicates and treatments: CONT (absolute control); CM (control with cattle manure fertilization); CMB (with fertilization and Pseudomonas sp.); CMF (with fertilization and T. aureoviride) and CMBF (with fertilization and the two microorganisms combined). The fertilizer used was organic with cattle manure in a dose recommended for the culture. This study evaluated the production of lettuce, microbial biomass and the enzymatic activity of acid phosphatase, alkaline phosphatase and urease. The combined application of CMBF was efficient in increasing lettuce production, because it increased $85 \%$ of the $\mathrm{cv}$. Veronica cultivated on sandy soil. The combined use of plant growth promoting microorganisms resulted to an increase in microbial biomass. In lettuce crops, it is recommended to use $T$. aureoviride URM 5158 and Pseudomonas sp. UAGF 14 in lettuce crops, because improved lettuce production, improves the biochemical quality of soils measured by absolute and specific enzymatic activities per unit of microbial biomass.
\end{abstract}

Keywords: Lactuca sativa. Crop production. Urease. Phosphatases. Bovine manure.

\section{BIOMASSA MICROBIANA E ATIVIDADES ENZIMÁTICAS DE SOLO CULTIVADO COM ALFACE INOCULADO COM PROMOTORES DE CRESCIMENTO}

\begin{abstract}
RESUMO - Os micro-organismos promotores do crescimento de plantas vêm sendo estudados como uma importante ferramenta para o aumento da produção agrícola. Lactuca sativa (alface) é a hortaliça folhosa mais consumida em todo mundo. Inúmeros micro-organismos podem atuar de forma benéfica no crescimento desta cultura. O objetivo do presente trabalho foi avaliar a eficácia de isolados de Trichoderma e Pseudomonas sp. na biomassa microbiana, atividades enzimáticas em solo arenoso e produção da alface cultivada com alface. $\mathrm{O}$ experimento foi conduzido em delineamento experimental inteiramente casualizado com dez repetições, sendo os tratamentos: CONT (controle absoluto); CM (controle apenas com a fertilização); CMB (com fertilização e Pseudomonas sp.); CMF (com fertilização e T. aureoviride) e CMBF (com fertilização e os dois microorganismos combinados). A fertilização utilizada foi a orgânica pela adição de esterco bovino em dose recomendada para a cultura. Avaliou-se a produção de alface, a biomassa microbiana e a atividade enzimática da fostafase ácida, fosfatase alcalina e urease. A aplicação CMBF foi eficiente para o aumento na produção de alface, pois incrementou $85 \%$ da produção da cv. Verônica em solo arenoso. O uso combinado de microorganismos promotores de crescimento de plantas incrementam a biomassa microbiana. Recomenda-se o uso de T. aureoviride URM 5158 e Pseudomonas sp. UAGF 14 no cultivo de alface, pois além de melhorar a produção, melhora a qualidade bioquímica dos solos mensurados por atividades enzimáticas absolutas e específicas por unidade de biomassa microbiana.
\end{abstract}

Palavras-chave: Lactuca sativa. Produção. Urease. Fosfatases. Esterco bovino.

\footnotetext{
*Corresponding author

${ }^{1}$ Received for publication in $07 / 12 / 2017$; accepted in 03/08/2018

Paper extracted from project of microbial ecology of the soil-plant system discipline.

${ }^{2}$ Academic Unit of Garanhuns, Universidade Federal Rural de Pernambuco, Garanhuns, PE, Brazil; marcele-moraes@hotmail.com ORCID: 0000-0001-7325-4915, evmbio@gmail.com - ORCID: 0000-0001-5543-9414, daya_andrade@outlook.com - ORCID: 0000-00026391-7831, leandro dias1993@hotmail.com - ORCID: 0000-0002-7103-1176, ivokarlos@hotmail.com - ORCID: 0000-0002-7556-6047. ${ }^{3}$ Departament of Plant Sciences, Universidade Federal de Viçosa, Viçosa-MG, Brazil; argemiro.ufra@gmail.com - ORCID: 0000-00033199-2703.
} 


\section{INTRODUCTION}

Lettuce (Lactuca sativa L.) stands out as the most consumed leafy vegetable in the world. This is because it is a source of vitamins, fibers and minerals (PINTO et al., 2014), has a high nutritional value, is easy to acquire and has a year-long production at a low cost (SILVA et al., 2011).

According to ONU data, in 2012, the total world production of lettuce was 24.94 million tonnes. In Brazil, in 2011, the production was 1.27 million tons, and Brazil stood out as the largest consumer in South America (PINTO et al., 2014). However, this crop has been suffering from phytosanitary problems that can compromise production, reduce the quality of the product marketed and jeopardize the income of the producer.

An alternative to mitigate these losses is the application of microorganisms growth promoters (MGPs) which introduce some benefits, such as cooperating with plants to fight herbivorous insects, promoting growth and inducing resistance. These microorganisms may also influence the availability of micronutrients by solubilization, chelation and soil reactions (ADAK et al., 2016). Fungus of the Trichoderma genus has been studied by producing a series of extracellular enzymes (HARMAN et al., 2004), such as chitinases, lipases, proteases and glucanases, capable of degrading fungal cell walls (SILVA et al., 2016). These enzymes also act in the decomposition of plant residues as well as in the inhibition of pathogens, interfering with the development of plants (SHANMUGAIAH et al., 2009). In this way, they interfere significantly in the development of plants with important economic implications, such as the decrease of plant growth period and, therefore, the permanence of seedlings in the nurseries; increased productivity and plant production, as well as improved plant vigor to biotic or abiotic stresses (HAJIEGHRARI, 2010).

The use of plant growth promoting rhizobacteria (PGPRs) can accelerate plant growth through diverse mechanisms (BHATTACHARYYA; JHA, 2012). These rhizobacteria prevent the establishment of pathogens in the rhizosphere by producing antibiotics, siderophores or hydrolytic enzymes (SILVA et al., 2011). Among the PGPRs, the Pseudomonas genera, especially the fluorescent group (SPAEPEN; VANDERLEYDEN; OKON, 2009) stand out.

Studies with MGPs are scarce, but the study of carbon quantification of soil microbial biomass is important for assessing the size of the most active and dynamic reservoir of organic matter in the soil, which consists basically of fungi, bacteria and actinomycetes (OLIVEIRA; MENDES; VIVALDI, 2001). Another soil attribute that has also been studied because of its sensitivity to soil changes is enzymatic activities. This variable works as an effective indicator of soil quality, organic matter decomposition and nutrient availability resulting from management practices or the environment (DE MEDEIROS et al., 2015).

The objective of the present study was to evaluate the effectiveness of the application of Trichoderma and Pseudomonas spp. on lettuce production as well as the impact on microbial biomass and the enzymatic activity of sandy soil.

\section{MATERIAL AND METHODS}

Soil and organic matter collection

The experiment was conducted in a soil collected from the $(0-20 \mathrm{~cm}$ depth) layer in a dry forest of the semi-arid region of Pernambuco State, Brazil. The climate was predominantly hot and humid, as As' according to Köppen's classification, with dry summers. The soil was classified as a typical sandy Regolitic Neosol (SANTOS et al., 2012). This soil was considered sandy (sand $=880$ $\mathrm{g} / \mathrm{kg}$, clay $=40 \mathrm{~g} / \mathrm{kg}$ and silt $=80 \mathrm{~g} / \mathrm{kg}$ ). The soil chemical properties were as follows: $\mathrm{pH}\left(\mathrm{H}_{2} \mathrm{O}\right.$ 1: 2.5) $=4.5 ; \mathrm{P}=16.6 \mathrm{mg} / \mathrm{kg} ; \mathrm{K}=0.15 \mathrm{~mol}_{\mathrm{c}} / \mathrm{kg} ; \mathrm{Na}=0.28$ $\mathrm{mol}_{\mathrm{c}} / \mathrm{kg} ; \mathrm{Ca}=0.8 \mathrm{cmol}_{\mathrm{c}} / \mathrm{dm}^{3} ; \mathrm{Mg}=0.8 \mathrm{cmol}_{\mathrm{c}} / \mathrm{dm}^{3}$ and $\mathrm{Al}=0.15 \mathrm{cmol}_{\mathrm{c}} / \mathrm{dm}^{3}$.

Obtaining the isolates and preparing the inoculum

The fungal isolate used to promote lettuce growth was Trichoderma aureoviride Rifai URM 5158 obtained from the URM culture collection of the Federal University of Pernambuco - UFPE (https://www.ufpe.br/micoteca/). This fungus was selected because in previous studies, it was highly efficient in the production of chitinase and in the biocontrol of phytopathogens such as Fusarium solani (Mart.) Sacc. and Scytalidium lignicola Pesante (SILVA et al., 2016).

The bacterial isolate selected was Pseudomonas UAGF 14 from the collection of microbial cultures of the Microbial Genetics and Biotechnology Laboratory of the Universidade Federal Rural de Pernambuco - UFRPE. This bacterium was selected because it showed characteristics of plant growth promotion, such as the biological fixation of nitrogen, phosphate solubilization, indole-acetic acid synthesis and exopolysaccharide production (SANTOS et al., 2016).

The inoculum of $T$. aureoviride URM 5158 was prepared through the addition of 5 disks of 8 $\mathrm{mm}$ containing fungal mycelium, grown in a $250 \mathrm{ml}$ 
Erlenmeyer flask, containing $50 \mathrm{ml}$ of liquid potatoDextrose (P.D.) culture medium and incubated with 8 days of growth in B.O.D. Subsequently, these flasks were incubated at $26 \pm 2{ }^{\circ} \mathrm{C}$ for 8 days in B.O.D. The concentration of the inoculum was adjusted to $1 \times 10^{6}$ conidia $\mathrm{ml}^{-1}$ ), following the methodology of Abo-Elyousr, Abdel-Hafez and Abdel-Rahim (2014).

For bacterial inoculum formation, the isolate of Pseudomonas sp. UAGF 14 was inoculated in $10 \%$ Tryptone Soya (T.S.) medium using the depletion technique, in order to obtain colony isolation. Of these colonies, $10 \mathrm{ml}$ of T.S. was collected and stirred continuously for $24 \mathrm{~h}$. Then, the bacterial culture was diluted in phosphate buffered saline $\left(8 \mathrm{~g} \mathrm{~L}^{-1} \mathrm{NaCl} ; 0.2 \mathrm{~g} \mathrm{~L}^{-1} \mathrm{KCl} ; 1.44 \mathrm{~g} \mathrm{~L}^{-1}\right.$ $\mathrm{Na}_{2} \mathrm{HPO}_{4} ; 0.24 \mathrm{~g} \mathrm{~L}^{-1}$ of $\mathrm{KH}_{2} \mathrm{PO}_{4}$ at $\mathrm{pH} 7.4$ ). The inoculum obtained presented optical density (OD $600 \mathrm{~nm})$ of 0.095 .

Conducting the experiment

The experiment was conducted in Regolitic Neosol placed in plastic pots with a capacity of $4 \mathrm{~L}$. Two 'Veronica' lettuce seeds were grown in each pot. In the treatments that received Pseudomonas sp. UAGF 14, the seeds were inoculated by immersion in a suspension of the bacterial inoculum for $30 \mathrm{~min}$; and the material was agitated every $10 \mathrm{~min}$. Treatments that did not receive the bacterial inoculum were submitted to the same procedure and immersed in PBS buffer. Treatments that received the fungus were inoculated with $100 \mathrm{ml}$ of $T$. aureoviride URM 5158 ( 1 x $10^{6}$ conidia $\left.\mathrm{ml}^{-1}\right)$ directly to the soil, following the methodology of Abo-Elyousr, Abdel-Hafez and Abdel-Rahim (2014).

A completely randomized experimental design with five treatments and ten replicates was used for this study. The treatments were: CONT (absolute control); CM (control only with cattle manure fertilization); $\mathrm{CMB}$ (with fertilization and Pseudomonas sp. UAGF 14); CMF (with fertilization and T. aureoviride URM 5158) and CMBF (with fertilization and the two microorganisms combined).

The fertilizer used was organic, involving the addition of tanned bovine manure, available in the region and collected at the UFRPE Cattle Clinic in Garanhuns-PE. The concentration of the applied fertilizer was as recommended for the crop in the fertilization recommendation manual for the State of Pernambuco (CAVALCANTI et al., 2008).
Evaluation of lettuce production

After 60 days of sowing, lettuce production was evaluated by obtaining the dry biomass of the aerial part (tradable part), and it was calculated by the difference between dry and green matter.

Microbial biomass

At the same time, the soil samples of each treatment and repetition were collected near the roots of the plants. To determine the carbon of the microbial biomass (CMB), the soil samples were subjected to the irradiation process according to Mendonça and Matos (2005). The biomass extraction was carried out using $\mathrm{K}_{2} \mathrm{SO}_{4} \quad 0.5 \mathrm{M}$ extractor. For each $20 \mathrm{~g}$ of soil, $80 \mathrm{~mL}$ of $\mathrm{K}_{2} \mathrm{SO}_{4} 0.5$ $\mathrm{M}$ was added. Colorimetry was used to determine the carbon content of the extracts (BARTLETT; ROSS, 1988).

Enzymatic activities

The determination of urease activity was according to Kandeler and Gerber (1988). Samples of $5 \mathrm{~g}$ of soil were weighed and $2.5 \mathrm{~mL}$ of urea was added and incubated for $2 \mathrm{~h}$ at $37^{\circ} \mathrm{C}$. The reading was taken with a spectrophotometer (Libra S22, Biochrom, Cambridge, UK) at $690 \mathrm{~nm}$ of absorbance. The results were expressed as $\left(\mu \mathrm{g} \mathrm{\textrm {NH } _ { 4 } -}\right.$ $\mathrm{N} \mathrm{g}^{-1}$ soil $\left.\mathrm{h}^{-1}\right)$. The analyses were performed in triplicate, of each replicate.

The activities of acid and alkaline phosphatase were estimated as adapted from Tabatabai and Bremmer (1972). To $1 \mathrm{~g}$ samples were added $4 \mathrm{~mL}$ of MUB buffer ( $\mathrm{pH} 6.5)$ to determine the acid phosphatase activity and $4 \mathrm{~mL}$ of MUB buffer ( $\mathrm{pH} \mathrm{11)} \mathrm{was} \mathrm{added} \mathrm{to} \mathrm{determine} \mathrm{the} \mathrm{alkaline}$ phosphatase activity. The reading was performed at $400 \mathrm{~nm}$ absorbance. The result was calculated using the formulas established by Kandeler and Gerber (1988). The analyses were performed in triplicate of each replicate.

\section{Statistical analysis}

The production, microbial biomass and enzymatic activities data were subjected to analysis of variance (ANOVA) to determine whether the isolated or combined inoculation with growth promoting microorganisms interfered with these 
variables. Significant differences were separated by the Tukey test at the 5\% probability level. In order to evaluate if the microbial and biochemical attributes reflect on lettuce production, when inoculated with the microorganisms used in the experiment, the data were submitted to Pearson's correlation analysis, at the $5 \%$ probability level.

\section{RESULTS AND DISCUSSION}

The application of the two plant growth promoting microorganisms considerably increased $(\mathrm{p} \leq 0.05)$ the lettuce production (Figure 1). The use of T. aureoviride URM 5158 and Pseudomonas sp. UAGF 14 (CMBF) increased the lettuce yield by $85 \%$ when compared to the absolute control, without the addition of inoculants. All treatments increased lettuce yield, thereby demonstrating the efficiency of inoculation with the plant growth promoter microorganisms on the production of this crop.

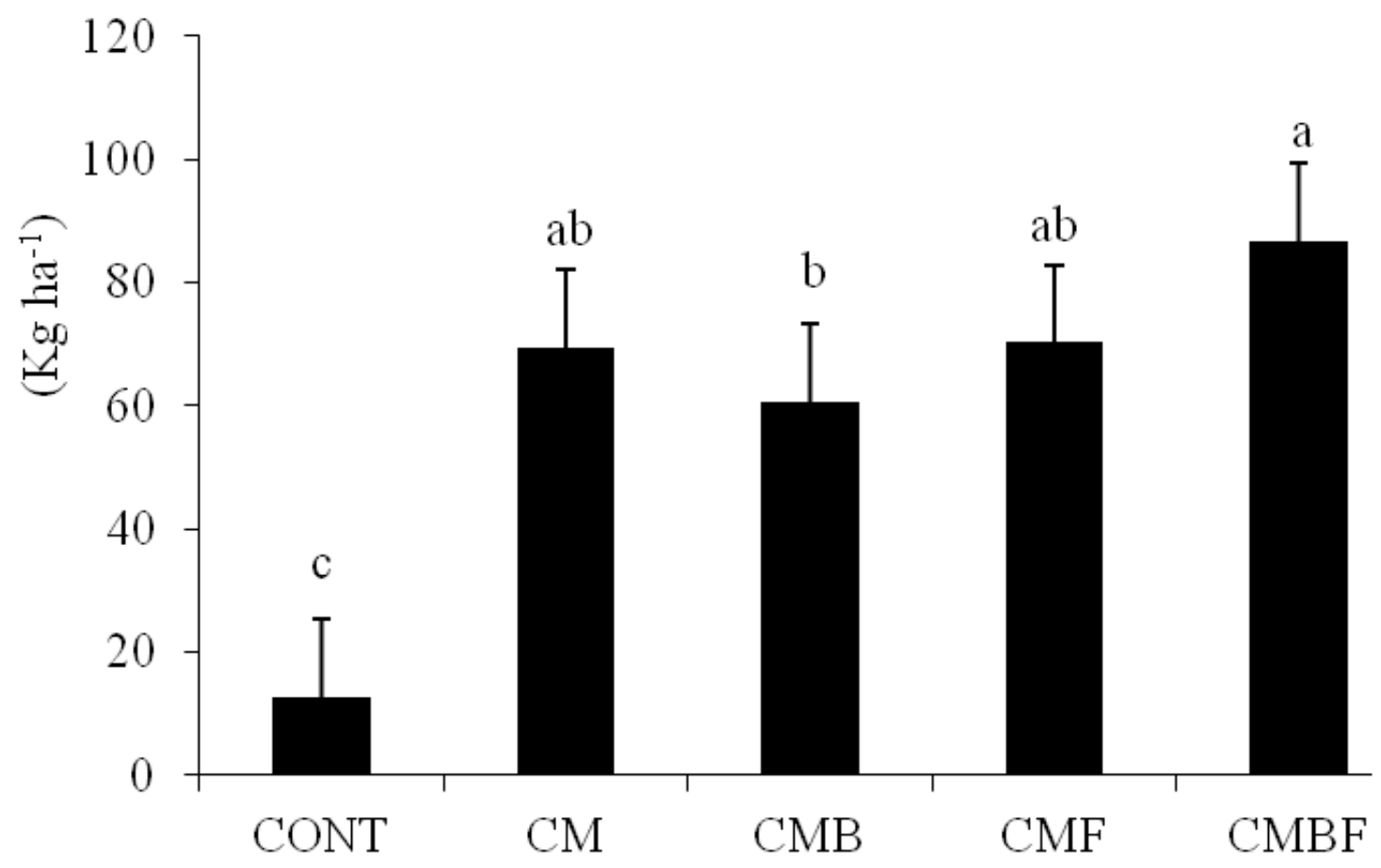

Figure 1. Lettuce production with and without the use of plant growth promoting microorganisms (Pseudomonas sp. UAGF 14 and Trichoderma aureoviride URM 5158) isolated and combined forms in Regollitic Neosol. CONT (absolute control); CM (control with cattle manure fertilization); CMB (with fertilization and Pseudomonas sp. UAGF 14); CMF (with fertilization and T. aureoviride URM 5158) and CMBF (with fertilization and the two microorganisms combined). Different letters indicate significant differences $(\mathrm{p}<0.05)$ by ANOVA, followed by the Tukey test.

Several studies have reported the ability of various genera of bacteria to promote plant growth. However, the genus Pseudomonas appears frequently in the literature. Pseudomonas spp. are common and abundant inhabitants of different geographic regions and produce a series of enzymes and metabolites of biotechnological importance involved in plant growth (DESHWAL; KUMAR, 2013).

Deshwal and Kumar (2013) showed an increase from 52.80 to $157.72,172.04$ to 408.06 and 93.15 to $233.84 \%$ for shoot dry weight, root dry weight and rice plant (Oryza sativa L.), respectively, relative to the control, when isolated rice seeds were inoculated with Pseudomonas strains ( $P$. aeruginosa Schroeter , P. putida Trevisan, P. cepacia Yabuuchi and $P$. fluorecens Flügge).
The application of Trichoderma spp. has caused significant increases in germination percentage and precocity, dry weight and plant height. In addition to stimulating the development of lateral roots (CONTRERAS-CORNEJO et al., 2009), they are capable of acting as biostimulants of root growth, promoting the development of roots through phytohormones and thus, improve the assimilation of nutrients, increasing resistance to unfavorable biotic factors, and degrading sources of nutrients that will be important for plant development (HARMAN et al., 2004).

Adkins (2010) studied the growth of tomato (Solanum lycopersicum L.) inoculated with Trichoderma, and reported that the fungus promoted higher plant growth, higher accumulation of fresh, dry and total matter. Lynck (1992) reported that the 
potential of Trichoderma spp. as a biological agent in agriculture is due to its ability to stimulate plant growth when incorporated into the substrate and it provided a 54 to $100 \%$ increase in lettuce production.

Following the same pattern of lettuce production, treatments that received inoculation with both microorganisms increased the microbial biomass of sandy soils cultivated with lettuce (Figure 2). Inoculation with $T$. aureoviride URM 5158 significantly altered the population of microorganisms evaluated by CBM, both applied alone and combined with the bacterium Pseudomonas sp. UAGF 14.

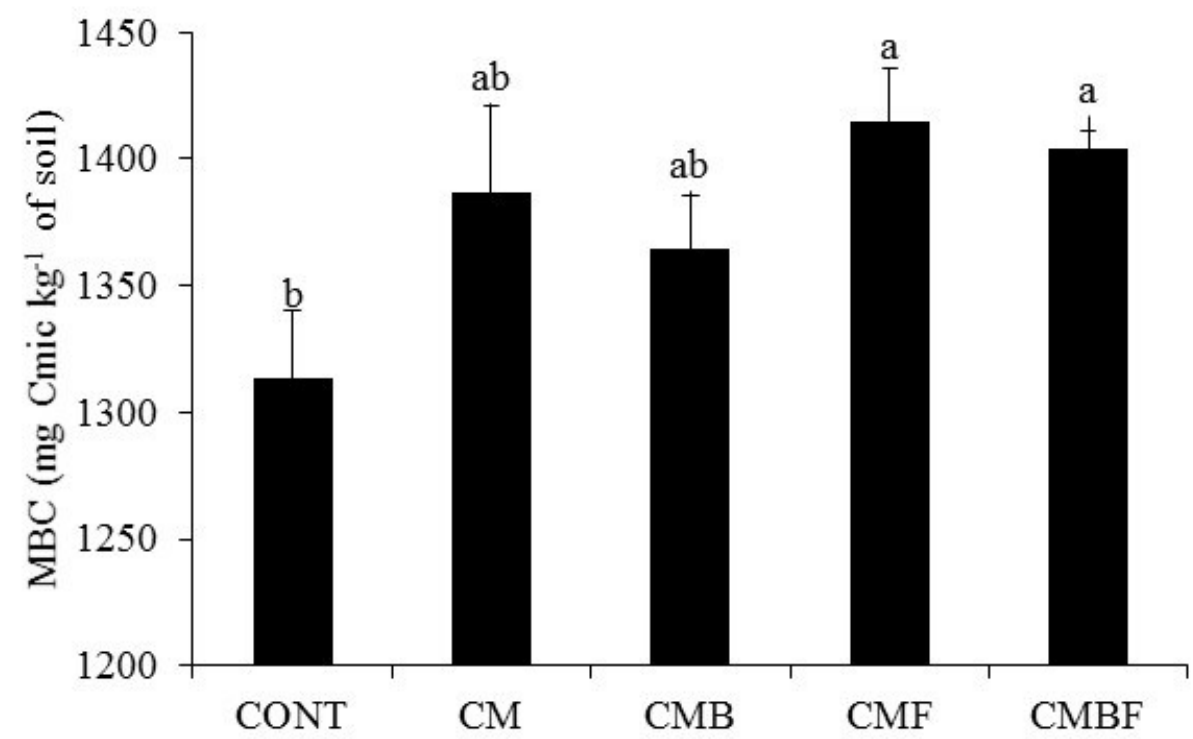

Figure 2. Microbial biomass carbon in Regolithic Neosol, cultivated with lettuce and without the use of plant growth promoting microorganisms (Pseudomonas sp. UAGF 14 and Trichoderma aureoviride URM 5158) isolated and combined forms in Regollitic Neosol. CONT (absolute control); CM (control with cattle manure fertilization); CMB (with fertilization and Pseudomonas sp. UAGF 14); CMF (with fertilization and T. aureoviride URM 5158) and CMBF (with fertilization and the two microorganisms combined). Different letters indicate significant differences $(\mathrm{p}<0.05)$ by ANOVA, followed by the Tukey test.

The application of plant growth promoting microorganisms (Pseudomonas sp. UAGF 14 and Trichoderma aureoviride URM 5158), both in isolation and in combination, compared to the control, exerted superior and beneficial effects on the microbial population, thus favoring biomass in Regolitc Neosol, cultivated with lettuce. The increase in microbial biomass can be explained as due to the availability of these bacteria to the plant and over time has played a fundamental role in maintaining soil fertility. Hence, it is stored temporarily in the biomass, thus making the microbial growth unlimited. The frequent use of crops with high production of residues makes possible the increase in biomass and a higher microbial activity.

However, the treatment that received the cattle manure was as efficient in increasing MBC as $\mathrm{CMBF}$, suggesting that manure is the main factor responsible for the increase in soil microbial biomass. In this study, the microbial population of manure was not evaluated, but several studies have reported that the addition of organic compounds increases the amount and diversity of soil microorganisms. This fact can be observed in an earlier study in which the same soil and manure were applied to induce cassava root rot. The authors showed that the fatty acid profile of the soil microbial community with manure showed higher concentrations and diversity of the FAMES, for example C18: 1 (9) cis which is indicative of saprophytic fungi, such as Trichoderma spp. (SILVA et al., 2017).

Here, the effect of using T. aureoviride URM 5158 and Pseudomonas sp. UAGF 14 for inoculation, on all soil enzymatic activities (Figure 3 ) is presented. Generally, inoculation with both growth promoting microorganisms increased $(p \leq 0.05)$ the urease and acid phosphatase activities in sandy soils cultivated with lettuce. However, alkaline phosphatase did not present a similar behavior to the others, because the control treatment presented similar contents of alkaline phosphatase when compared to the treatment that both microorganisms received (CMBF). 


\section{Urease}

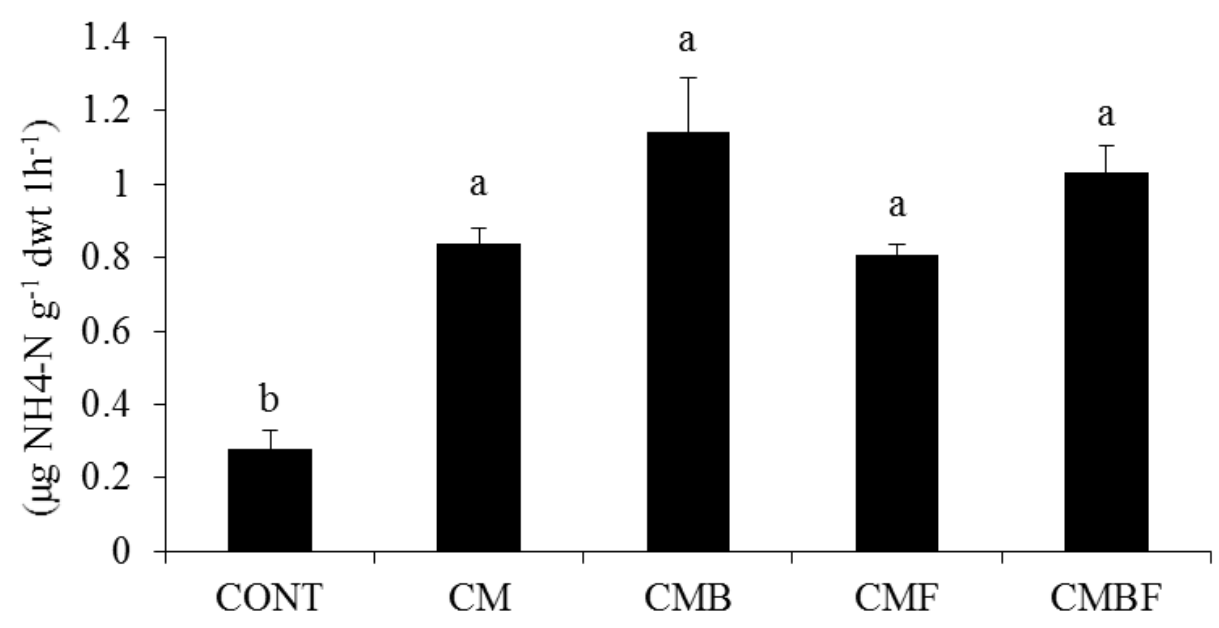

\section{Acid phosphatase}
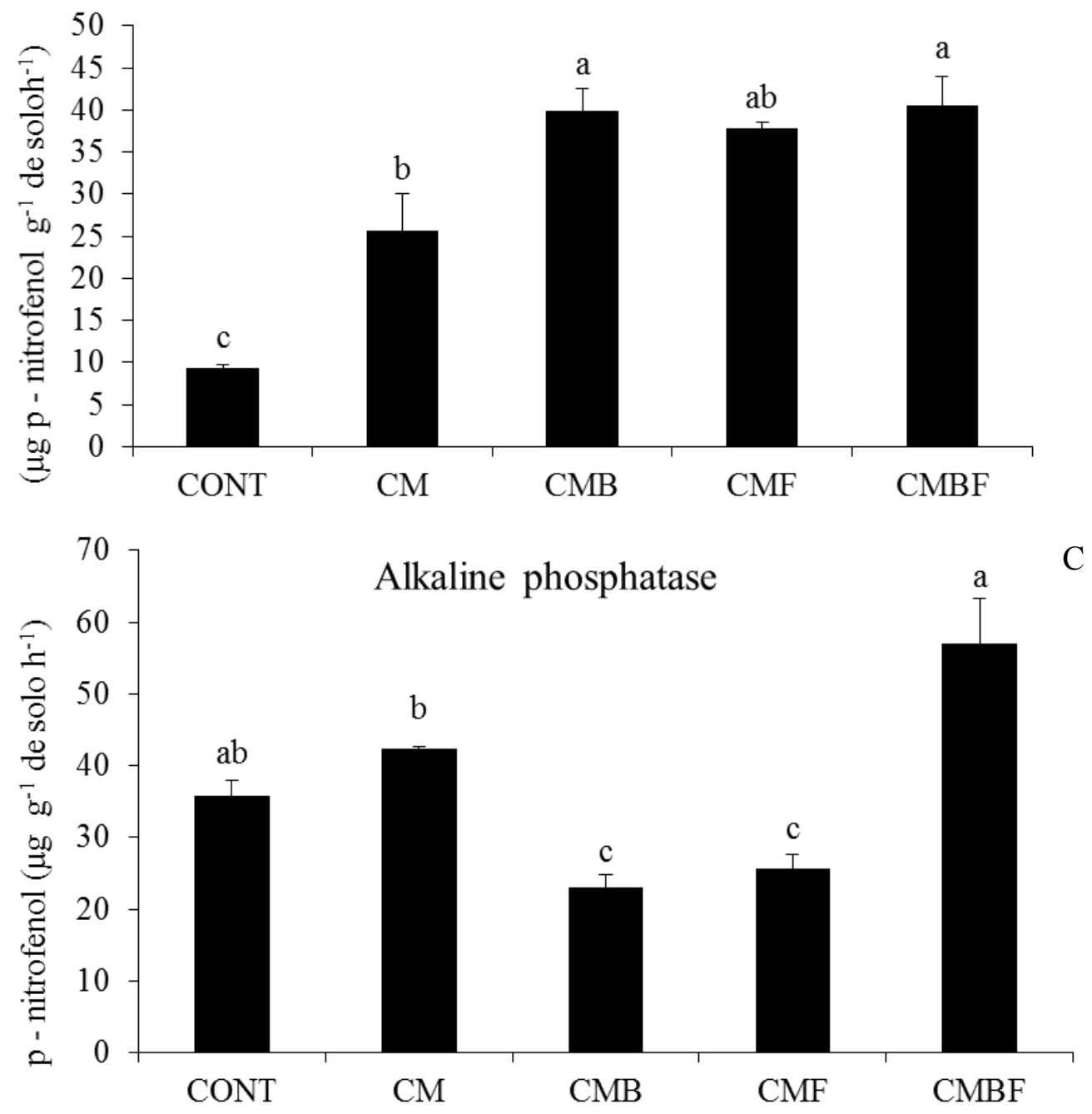

Figure 3. a) Urease, b) Acid phosphatase and c) Alkaline phosphatase in Regolithic Neosol, cultivated with lettuce with and without the use of plant growth promoting microorganisms (Pseudomonas sp. UAGF 14 and Trichoderma aureoviride URM 5158) isolated and combined forms in Regollitic Neosol. CONT (absolute control); CM (control with cattle manure fertilization); CMB (with fertilization and Pseudomonas sp. UAGF 14); CMF (with fertilization and $T$. aureoviride URM 5158) and CMBF (with fertilization and the two microorganisms combined). Different letters indicate significant differences $(\mathrm{p}<0.05)$ by ANOVA, followed by the Tukey test. 
Urease and phosphatase are primary enzymes which are micro-produced and essential to the nitrogen and phosphorus cycles in various soil ecosystems. Urease is an indicator of soil quality for nitrogen cycling, and it acts on organic matter that contains nitrogen, mainly urea, and produces $\mathrm{NH}_{3}$ of inorganic nitrogen, which is then transformed into $\mathrm{NH}_{4}^{+}$by soil microbial biomass and is available for plant absorption (LI et al., 2017). The soil microbial community consisting of bacteria or soil fungi converts organic nitrogen $\left(\mathrm{N}^{-}\right)$to ammonia $\left(\mathrm{NH}_{4}^{+}\right)$, while urease catalyzes the hydrolysis of urea into carbon dioxide and ammonia (SEE-TOO et al., 2017).

Trichoderma is a known biocontrol fungus as a result of its effective function against a large amount of plant pathogens as well as its ability to promote plant growth. In this process, plants and soil microorganisms generally influence each other. Soil enzymes are mainly produced by soil microorganisms and the enzymatic activities are closely related to the number, diversity and microbial biomass of the soil, as verified in the present study in which the behavior of the CBM followed a pattern similar to the activity of urease and phosphatase.

Pseudomonas is among the most commonly reported bacteria with an unusually versatile metabolism. Certain isolates of Pseudomonas presented AHL (N-acyl-homoserine lactones) acylase activity, an enzyme that can degrade $\mathrm{N}$-acylhomoserine lactones (AHLs), allowing the use of this compound as nitrogen and energy sources. Such bacteria can be used as biological control agents in cold environments in high latitudes or in temperate regions (SEE-TOO et al., 2017). Some soil microorganisms, such as Pseudomonas sp., are capable of producing ureases (CAO; WANG; JI, 2016); this corroborates the present study, because the treatments that received the bacteria (CMB and $\mathrm{CMBF}$ ) showed higher soil urease activities.

In this study, the enzymatic activity of urease was significantly increased after the application of $T$. aureoviride URM 5158 and Pseudomonas sp. UAGF 14 , suggesting that these treatments improved the number, diversity and microbial biomass of the soil, and may have increased soil fertility. It therefore functions as a mechanism of promoting plant growth. When applied in isolation, the bacterium (Pseudomonas sp.) showed a similar behavior, increasing the activity of this enzyme because of its ability to secrete urease. The phosphatase activity indicates the phosphorus cycle in the soil-plant system, which hydrolyzes phosphorus in organic form in phosphate that is available to plants. The phosphatase activity in the soil is considered to be of microbial origin (LI et al., 2017). Microorganisms are important for plants to improve the availability of phosphorus, among which some species of the genus Trichoderma are known to be producers of acid phosphatase (LEI; ZHANG, 2015).

Similar results were obtained by Rajeela et al. (2017), who evaluated the cross-compatibility of rhizobacteria growth promoters of coconut (Cocos nucifera L.) and cocoa (Theobroma cacao L.) on the yield properties and rhizosphere of vegetables. These authors showed that the enzymatic activities of phosphatase and urease increased because Pseudomonas increased the amount of microorganisms in the soil, especially the phosphate solubilizing bacteria, and nitrogen fixers.

Alkaline phosphatase also solubilizes phosphate compounds. In all bacteria, including those of the genus Pseudomonas, this enzyme catalyzes the hydrolysis of a wide variety of phosphorus-monomers and the transphosphorylation (reaction by transferring the phosphoryl group to the alcohol in the presence of phosphate). Alkaline phosphatase is directly linked to soil $\mathrm{pH}$. Since the bacterium Pseudomonas is among the main microorganisms catalyzing the solubilization of soil phosphates, the production of this enzyme by this bacterium occurs at an ideal $\mathrm{pH}$ between 7 and 8.5 . This corresponds to the ideal $\mathrm{pH}$ range for the growth of most bacteria and for alkaline phosphatase secretion (BEHERA et al., 2017). The main sources of alkaline phosphatase activity are bacteria, whereas the activity of acid phosphatase is in bacteria, fungi and plants (NARENDRULA-KOTHA; NKONGOLO, 2017).

Therefore, soil bacteria including Pseudomonas, can activate the expression of acid phosphatase, and the relationship between alkaline phosphatase activity and fungi, such as Trichoderma, may be positive or neutral (LUO; MENG; GU, 2017). In this way, the incubation of soil with both microorganisms could possibly inhibit alkaline phosphatase activity.

When specific enzymatic activities were evaluated per unit of microbial carbon, the largest specific enzymatic activities were quantified in soils that received the combined inoculation of $T$. aureoviride URM 5158 and Pseudomonas sp. UAGF 14, CMBF treatment (Figure 4). Soils cultivated with lettuce plants and treated with isolated plant growth promoters also had high specific enzymatic activities when compared to the control treatment. 


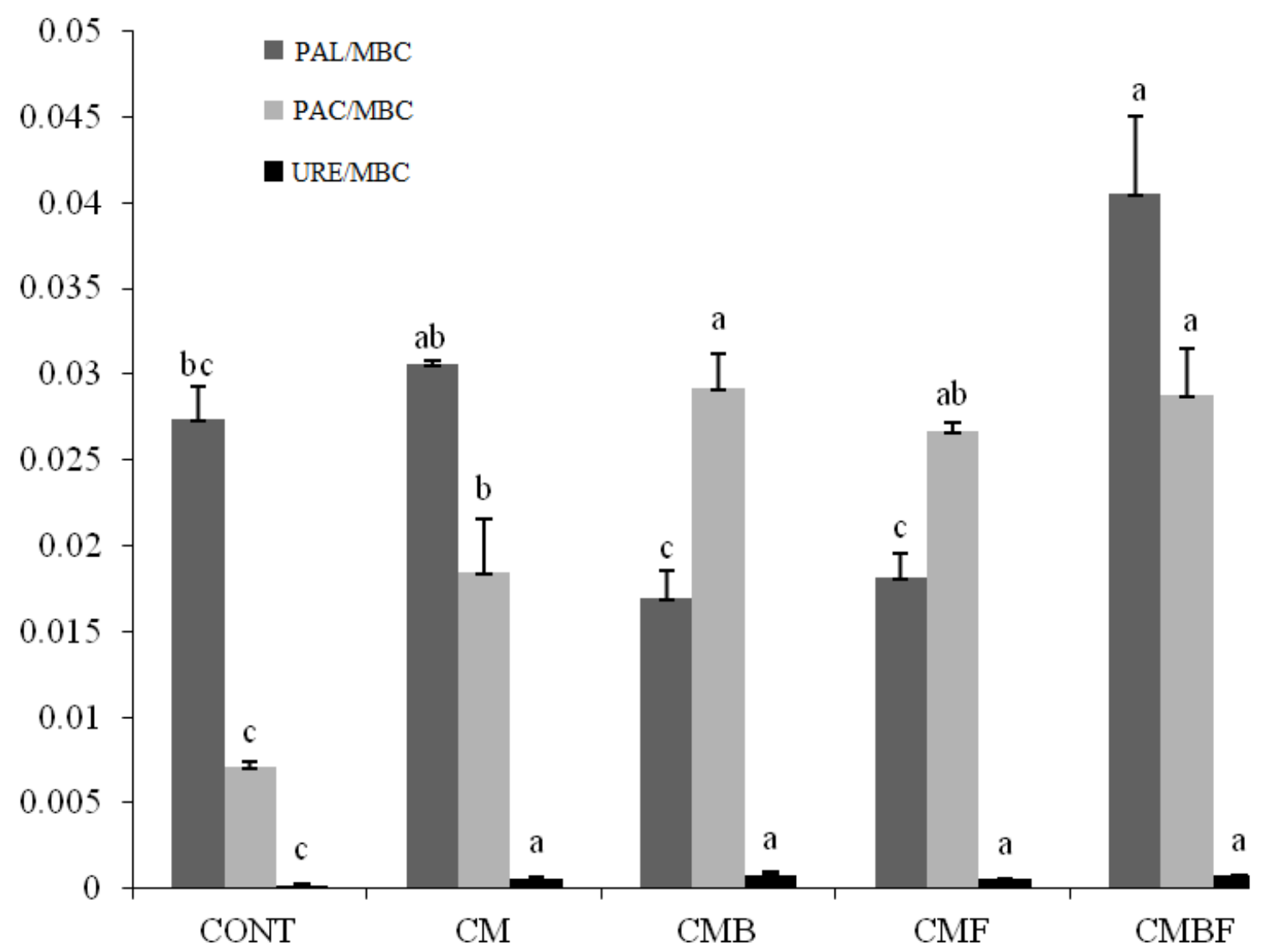

Figure 4. Specific enzymatic activities per unit carbon of microbial biomass (URE / MBC $=$ Urease, $\mathrm{PAC} / \mathrm{MBC}=\mathrm{Acid}$ phosphate and PAL / MBC = Alkaline phosphatase) in Regolithic Neosol, cultivated with lettuce with and without the use of plant growth promoting microorganisms (Pseudomonas sp. UAGF 14 and Trichoderma aureoviride URM 5158) isolated and combined forms in Regollitic Neosol. CONT (absolute control); CM (control with cattle manure fertilization); CMB (with fertilization and Pseudomonas sp. UAGF 14); CMF (with fertilization and T. aureoviride URM 5158) and CMBF (with fertilization and the two microorganisms combined). Different letters indicate significant differences $(\mathrm{p}<0.05)$ by ANOVA, followed by the Tukey test.

The higher specific enzymatic activities per unit of microbial carbon may imply more metabolically active microorganisms in the soils or increased enzymatic efficiency (that is, higher enzymatic synthesis by the soil microflora). This study showed that the enzymatic activity per MBC unit in soils inoculated with the two microorganisms increased the efficiency of the enzymatic activities and may also be an adequate indicator in detecting the effect of changes in land use in the active microbial community (RAIESI; BEHESHTI, 2014).

The specific enzyme activity also provides information on the metabolic status of microbial community changes, enzymatic efficiency, and ecology-related information on the activities of immobilized extracellular enzymes. In addition, specific enzyme activity can also serve as a functional indicator with direct ecological impacts and, therefore, can be more easily used as an indicator of changes in the composition of the soil microbial community. In comparison to the absolute enzyme activity, specific enzymatic activity can be used to normalize the differences in MBC in the different treatments and is a more accurate measure for comparing the extent to which different treatments affect the functioning of the soil microbial community (LIU et al., 2017).

Pearson's correlation analyses were performed to determine which soil parameters correlated with production. All the variables analyzed were positively correlated with lettuce production when inoculated with growth promoters, except for the absolute alkaline phosphatase and specific alkaline phosphatase per MBC unit (Table 1). The production of lettuce inoculated with T. aureoviride URM 5158 and Pseudomonas sp. UAGF 14 increased with increasing MBC, as well as the absolute and specific enzymatic activities. This confirmed that the use of growth promoting microorganisms can improve production directly or indirectly, influence the microbial communities that are responsible for various reactions and the availability of nutrients and oxidation / reduction reactions in the soil (ADAK et al., 2016). 
Table 1. Correlation between production and the microbial and biochemical attributes of Regolitic Neosol cultivated with lettuce with and without the use of plant growth promoter microorganisms (Pseudomonas sp. UAGF 14 and Trichoderma aureoviride URM 5158) in isolated and combined forms.

\begin{tabular}{lc}
\hline & Produção \\
\hline Microbial biomass carbono (MBC) & $0.93^{*}$ \\
Urease (URE) & $0.85^{*}$ \\
Alkaline phosphatase (PAL) & $0.33^{\text {ns }}$ \\
Acid phosphatase (PAC) & $0.87^{*}$ \\
URE/MBC & $0.82^{*}$ \\
PAL/MBC & $0.26^{\text {ns }}$ \\
PAC/MBC & $0.86^{*}$ \\
\hline
\end{tabular}

\section{CONCLUSIONS}

The combined application of $T$. aureoviride URM 5158 and Pseudomonas sp. UAGF 14 is efficient for the increased production of 'Verônica' lettuce, causing an increase of $85 \%$ in sandy soil products.

The combined use of plant growth promoting microorganisms increased the microbial quality of sandy soil, resulting in increased microbial biomass.

It is recommended that $T$. aureoviride URM 5158 and Pseudomonas sp. UAGF 14 should be used in lettuce cultivation, because in addition to improving production, these microbes enhance the biochemical quality of soils measured by absolute and specific enzymatic activities per unit of microbial biomass.

\section{ACKNOWLEDGMENTS}

The authors are grateful to $\mathrm{CNPq}$ for their financial support (Process 481436 / 2010-3 and 562584 / 2010-2), CAPES and the corresponding author's productivity grant (306401 / 2015-0). The authors also thank the researchers Júlia KuklinskySobral and Cristina Souza-Motta for assigning the microorganisms used in this study.

\section{REFERENCES}

ABO-ELYOUSR, K. A. M.; ABDEL-HAFEZ, S. II; ABDEL-RAHIM, I. R. Isolation of Trichoderma and evaluation of their antagonistic potential against $\mathrm{Al}$ ternaria porri. Journal of Phytopathology, Göttingen, v. 162, n. 9, p. 567-574, 2014.

ADAK, Anurup et al. Micronutrient enrichment mediated by plant-microbe interactions and rice cultivation practices. Journal of Plant Nutrition, Georgia, v. 39, n. 9, p. 1216-1232, 2016.

ADKINS, B. J. Overall growth of tomato (Lycopersicon esculentum L. cv. Glacier) inoculated with species of glomus and trichoderma growing under greenhouse conditions. 2010, 24 p. Dissertação (Horticulture and Crop Science Department), California Polytechnic State University, San Luis Obispo, California, 2010.

BARTLETT, R. J.; ROSS, D. S. Colorimetric determination of oxidizable carbon in acid soil solutions. Soil Science Society American Journal, Madison, v. 52, n.4, p. 191-192, 1988.

BEHERA, B. C. et al. Alkaline phosphatase activity of a phosphate solubilizing Alcaligenes faecalis, isolated from Mangrove soil. Biotechnology Research and Innovation, Rio de Janeiro, v. 1, n.1, p. 101-111, 2017.

BHATTACHARYYA, P. N.; JHA, D. K. Plant growth-promoting rhizobacteria (PGPR): emergence in agriculture. World Journal of Microbiology and Biotechnology, Hull, v. 28, n. 4, p. 1327-1350, 2012.

CAO, J.; WANG, C.; JI, D. Improvement of the soil nitrogen content and maize growth by earthworms and arbuscular mycorrhizal fungi in soils polluted by oxytetracycline. Science of The Total Environment, Barcelona, v. 571, n.1, p. 926-934, 2016.

CAVALCANTI, J.A. et al. Recomendações de adubação para o estado de Pernambuco. Comissão estadual de fertilidade do solo. 2. ed. Recife, PE: IPA, 2008. 211 p.

CONTRERAS-CORNEJO, H. A. et al. Trichoderma virens, a plant beneficial fungus, enhances biomass production and promotes lateral root growth through an auxin-dependent mechanism in Arabidopsis. Plant Physiology, Glasgow, v. 149, n. 3, p. 15791592, 2009. 
DE MEDEIROS, E. V. et al. Absolute and specific enzymatic activities of sandy entisol from tropical dry forest, monoculture and intercropping areas. Soil and Tillage Research, Amsterdam, v. 145, n.1, p. 208-215, 2015.

DESHWAL, V. K.; KUMAR, P. Plant growth promoting activity of Pseudomonads in rice crop. International Journal of Current Microbiology Applied Science, Tamilnadu, v. 2, n. 11, p. 152 - 157, 2013.

HAJIEGHRARI, B. Effects some Iranian Trichoderma isolates on maize seed germination and seedling vigor. African Journal of Biotecnology, Kunming, v. 9, n.28, p. 4342-4347, 2010.

HARMAN, G. E. et al. Trichoderma species - opportunistic, avirulent plant syimbionts. Nature, London, v. 2, n.1, p .43-56, 2004.

KANDELER, E.; GERBER, H. Short-term assay of soil urease activity using colorimetric determination of ammonium. Biology and fertility of Soils, Firenze, v. 6, n. 1, p. 68-72, 1988.

LEI, Z. H. A. O.; ZHANG, Ya-qing. Effects of phosphate solubilization and phytohormone production of Trichoderma asperellum Q1 on promoting cucumber growth under salt stress. Journal of Integrative Agriculture, Beijing, v. 14, n. 8, p. 1588-1597, 2015.

LI, B. et al. Influence of cerium oxide nanoparticles on the soil enzyme activities in a soil-grass microcosm system. Geoderma, Beijing, v. 299, n.1, p. 5462, 2017.

LIU, S. et al. Rice husk biochar impacts soil phosphorous availability, phosphatase activities and bacterial community characteristics in three different soil types. Applied Soil Ecology, Firenze, v. 116, n.1, p. 12-22, 2017.

LUO, L.; MENG, H.; GU, J. D. Microbial extracellular enzymes in biogeochemical cycling of ecosystems. Journal of Environmental Management, Sint-Katelijne-Waver, v. 197, n.1, p. 539-549, 2017.

LYNCK, J. Pesquisa inglesa com agentes biológicos. Jornal Agroceres, São Paulo, v. 212, s/n., p. 2, 1992.

MENDONÇA, E. S,; MATOS, E. S. Matéria orgânica do solo: Métodos de análises. 1. ed. Viçosa, MG: UFV. 2005. 107p.

NARENDRULA-KOTHA, R.; NKONGOLO, K. K. Changes in enzymatic activities in metal contamina- ted and reclaimed lands in Northern Ontario (Canada). Ecotoxicology and Environmental Safety, Plymouth, v. 140, n.1, p. 241-248, 2017.

OLIVEIRA, J. R. A.; MENDES, I. C.; VIVALDI, L. Carbono da biomassa microbiana em solos de cerrado sob vegetação nativa e sob cultivo: avaliação dos métodos fumigação-incubação e fumigaçãoextração. Revista Brasileira de Ciência do Solo, Viçosa, v. 25, n. 4, p. 863-871, 2001

PINTO, A.A. et al. Changes in macrominerals, trace elements and pigments content during lettuce (Lactuca sativa L.) growth: Influence of soil composition. Food Chemistry, Norwich, v.152, n. 1, p. 603-61, 2014

RAIESI, F.; BEHESHTI, A. Soil specific enzyme activity shows more clearly soil responses to paddy rice cultivation than absolute enzyme activity in primary forests of northwest Iran. Applied Soil Ecology, Firenze, v. 75, n.1, p. 63-70, 2014.

RAJEELA, T. K. et al. Cross-compatibility evaluation of plant growth promoting rhizobacteria of coconut and cocoa on yield and rhizosphere properties of vegetable crops. Biocatalysis and Agricultural Biotechnology, Illinois, v. 9, n.1, p. 67-73, 2017.

SANTOS, I. B. et al. Desenvolvimento inicial de plântulas de feijão caupi: inoculação bacteriana $\mathrm{x}$ adubação mineral (NPK). Ciência \& Tecnologia, Piracicaba, v. 8, Sup., 2016.

SANTOS J. C. B. et al. Caracterização de Neossolos Regolíticos da região semiárida do estado de Pernambuco. Revista Brasileira de Ciência do Solo, Viçosa, v. 36, n.3, p. 683-96, 2012.

SEE-TOO, W. S. et al. Pseudomonas versuta sp. nov., isolated from Antarctic soil. Systematic and Applied Microbiology, Bremen, v. 40, n. 4, p. 191198, 2017.

SHANMUGAIAH, V. et al. Effect of single application of Trichoderma viride and Pseudomonas fluorences on growth promotion in cotton plants. African Journal of Agricultural Research, Kunming, v. 4, n.11, p. 1220-1225, 2009.

SILVA, E. M. N. C.P. da et al. Qualidade de alface crespa cultivada em sistema orgânico, convencional e hidropônico. Horticultura Brasileira, Vitória da Conquista, v. 29, n. 2, p. 242-245, 2011.

SILVA, J. A. T. da et al. Trichoderma aureoviride URM 5158 and Trichoderma hamatum URM 6656 are biocontrol agents that act against cassava root rot through different mechanisms. Journal of Phytopa- 
thology, Göttingen, v. 164, n. 11-12, p. 1003-1011, 2016.

SILVA, J. M. et al. FAMES and microbial activities involved in the suppression of cassava root rot by organic matter. Revista Caatinga, Mossoró, v. 30, n. 3, p. 708-717, 2017.

SPAEPEN, S.; VANDERLEYDEN, J.; OKON, O. Plant growth-promoting actions of rizobactheria. Advances in Botanical Research, Lorraine, v. 51, n. 2, p. 283-320, 2009.

TABATABAI, M. A.; BREMNER, J. M. Assay of urease activity in soils. Soil Biology and Biochemistry, Leicestershire, v. 4, n. 4, p. 479-487, 1972. 